\title{
Planning a Masterplan for the Sunrise Beach Area in an Effort to Develop Sustainable Tourism in Sanur, South Denpasar Sub-district, Denpasar, Bali
}

\author{
Ida Bagus Gede Parama Putra ${ }^{1}$, Ida Bagus Udayana Putra S.E., M.M. ${ }^{2}$, Ni Putu Ratih Pradnyaswari \\ Anasta Putri ${ }^{3}$ \\ \{Parama.putra@gmail.com ${ }^{1}$ \} \\ ${ }^{1,3}$ Department of Architecture, Faculty of Engineering and Planning, Warmadewa University
${ }^{2}$ Department of Management, Faculty of Economics and Business, Warmadewa University
}

\begin{abstract}
Sanur Kaja Village is a South Denpasar area with a lot of potential coastal beaches that offer beautiful sunrise panorama. Based on the current zoning and categorization of beaches in Sanur, Sunrise Beach has great potential, however, itneeds attention and potential development of the surrounding environment. Currently, this beach is located in an area known as boat crossing access to Nusa Penida and a religious ceremonial path for the Hindu community. This intersection led to a change in the image of this coastal area. This beach has a lot of potential, in accordance with tourism development such as the typical culinary, the atmosphere of the Black sand beach which is one of the natural potentials, and the mangrove forest area which can be further developed. Related to the development of Sanur tourism which includes the development of the Sunrise beach, the Ministry of Tourism has collaborated with UNWTO or the World Tourism Organization in the Sustainable Tourism Observatory (STO) program which aims to provide systematic monitoring to understand the responsible use of natural and human resources. This community partnership program collaborated with the Customary Village Owned Enterprises and is supported by the Sanur Development Foundation which is a group appointed to carry out the development of sunrise beach area. The service starts with the study and interview of local leaders in order to obtain concrete problems. The method used in the implementation of this service is interviews with the community and stakeholders, literature review as well as case studies of similar projects. This method has the ability to formulate and explore the potential of the region to support the creation of the Sunrise Beach Area Master Plan. Lack of feasibility studies and experts to formulate the development are some of the obstacles in decision making process. The output to be achieved is a study on the planning of Master Plan for the Sunrise Beach Area.
\end{abstract}

Keywords: Sunrise Beach, Ecotourism, Coastal Tourism, Sustainable Development 


\section{Pendahuluan}

Kawasan Sanur memiliki tujuh pantai yaitu, Pantai Merta Sari, Pantai Semawang, Pantai Batu Jimbar, Pantai Karang, Pantai Segara Ayu, Pantai Sindhu, dan Pantai Matahari Terbit yang menjadi objek pengabdian. Secara administratif, pantai Matahari Terbit terletak di bagian kota Denpasar, terletak di sebagian Kecamatan Denpasar Selatan yaitu terdiri di wilayah kelurahan Sanur, wilayah Desa Sanur Kota, wilayah Desa Sanur Kaja. Kawasan Sanur secara umum dan Pantai Matahari Terbit secara khusus merupakan daerah yang relatif datar sehingga berpotensi untuk tergenang di beberapa tempat pada musim hujan. Dikarenakan kondisi topografi seperti tersebut, maka aspek perencanaan dan penataan Kawasan harus mempertimbangkan sistem permukaan atau sistem drainase.

Berdasarkan Undang-Undang Republik Indonesia Nomor 10 Tahun 2009 pada butir 10 menyatakan Tentang Kepariwisataan

"Kawasan Strategis Pariwisata adalah kawasan yang memiliki fungsi utama pariwisata atau memiliki potensi untuk pengembangan pariwisata yang mempunyai pengaruh penting dalam satu atau lebih aspek, seperti pertumbuhan ekonomi, sosial dan budaya, pemberdayaan sumber daya alam, daya dukung lingkungan hidup, serta pertahanan dan keamanan"

Berdasarkan undang-undang tersebut Pantai Matahari Terbit memiliki potensi yang menjanjikan untuk dijadikan wisata baru. Pengembangan kepariwisataan di kawasan pariwisata Sanur lebih berorientasi ke pantai namun pada objek ini penataan akan berfokus pada peningkatan ekonomi, kelestarian lingkungan dan pemanfaatan lahan-lahan pasif yang belum terencana dengan baik. Terkait pengembangan wisata ini, Sustainable tourism menjadi sebuah acuan untuk perencanaan pengembangan wisata berkelanjutan yang selalu di canangkan oleh Kementerian Pariwisata (Kemenpar) yang disebut program Sustainable tourism Observatory (STO) yang menggandeng 5 Perguruan Tinggi di Indonesia. Pengembangkan destinasi pariwisata berkelanjutan. UNWTO atau World Tourism Organisation sebagai induk lembaga yang menjalankan program International Network of Sustainable tourism Observatories (INSTO) yang didirikan pada tahun 2004 dengan tujuan utama untuk mendukung peningkatan berkelanjutan dari keberlanjutan dan ketahanan di sektor pariwisata melalui pemantauan sistematis dan tepat waktu atas kinerja dan dampak pariwisata dan untuk menghubungkan tujuan-tujuan khusus untuk lebih memahami penggunaan sumber daya di seluruh tujuan dan mendorong pengelolaan pariwisata yang bertanggung jawab. Sanur terpilih menjadi anggota sejak tahun 2017 sehingga upaya peningkatan dan perencanaan dipantau oleh aspek pariwisata yang berkelanjutan dengan menekankan pada kelestarian alam, ekonomi kerakyatan dan peningkatan sosial budaya setempat (The International Network of Sustainable tourism Observatories (INSTO)).

\section{Permasalahan Mitra}

Permasalahan mitra jika ditinjau dari data yang diperoleh dari wawancara mitra dan survei lapangan diperoleh empat aspek yang perlu kajian lebih mendalam untuk dibenahi lebih lanjut karena hal dibawah mempengaruhi tingkat pengunjung Pantai Matahari Terbit terbilang sangat minim atau kurang diminati. Berikut penjabaran permasalahan mitra: 


\subsection{Petunon}

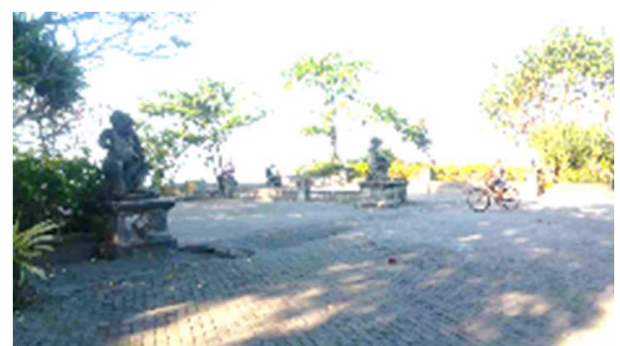

Gambar 1 Kondisi Petunon

Sumber : Penulis

Jalan utama menuju Pantai Matahari Terbit juga terhubung juga dengan lokasi Petunon atau tempat pembakaran mayat. Hal ini berdampak pada persepsi masyarakat lokal terhadap fungsi sekala dan niskala yang kental di Bali sehingga perencanaan Kawasan Pantai Matahari Terbit harus mewadahi fasilitas dua fasiltias yang berbeda dengan menciptakan citra kawasan wisata.

\subsection{Jalur Penyeberangan}

Dampak ekonomi dari adanya jalur penyeberangan menuju Nusa Penida dinilai sangat berpengaruh tinggi dalam pengembangan outlet atau toko sekitar. Dalam kurun lima tahun terakhir terlihat pengembangan ruko, rumah makan, café dan apartment semakin pesat. Namum dampak yang terjadi yaitu limbah minyak yang mencederai laut sekitar daerah parkir perahu.

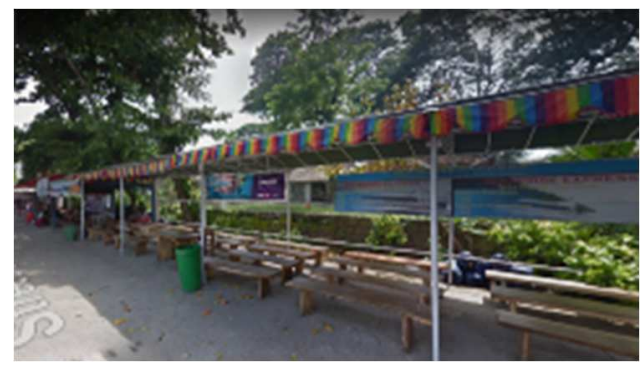

Gambar 2 Kondisi Petunon

Sumber : Penulis

\subsection{Destinasi dan Atraksi}

Pantai Matahari Terbit kurang memiliki destinasi dan atraksi yang menarik sehingga kurang menarik perhatian para wisatawan yang melintasi wilayah Sanur. Aspek ini akan dikaji lebih lanjut untuk meningkatkan citra kawasan yang lebih dikenal sebagai jalur upacara Ngaben. 


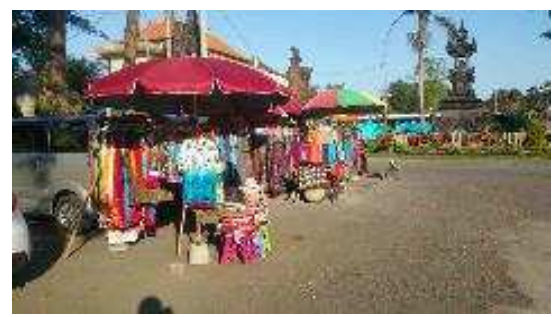

Gambar 3 Penjual suvenir

Sumber : Penulis

\subsection{Kuliner}

Pantai Matahari Terbit memiliki zona kuliner yang terletak di pinggir pantai yang memiliki banyak potensi antara lain kuliner laut yang segar dan hidangan nusantara lainnya. Selain potensi kuliner ikan laut, proses penangkapan ikan dan kegiatan jual beli juga menjadi aktivitas yang unik untuk dikembangkan. Namun lokasi warung yang berada diantara batu pemecah ombak menyebabkan pemandangan tidak langsung menuju horison laut yang merupakan potensi yang bisa ditingkatkan. Aspek lainnya yang kurang dikembangkan yaitu aspek keindahan warung yang masih menggunakan terpal yang tidak mencerminkan daerah wisata (Lihat gambar 1.4). Selanjutnya aspek ekomoni dan manajemen juga harus diperhatikan untuk kebutuhan promosi

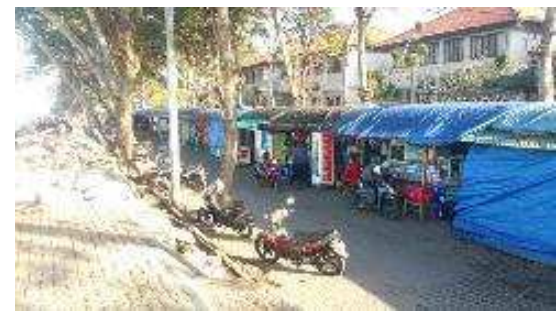

Gambar 4 Area Kuliner kawasan Matahari Terbit. Sumber: Penulis

\subsection{Ekonomi Kreatif dan Manajemen}

Permasalahan lainnya yaitu aspek ekonomi yang memerlukan kajian lebih lanjut dalam sistem manajemen dan pengembangan produk dalam hal ini aspek ekonomi kreatif menjadi salah satu penggerak terciptanya ide yang original yang berkonsep invovasi dan memiliki nilai lokalitas yang tinggi. Ekonomi kreatif memiliki peran sangat efektif dan sangat menguntungkan secara ekonomi, moral, budaya, alam, dan lingkungan masyarakat (Geriya, 2000). John Howkins (2001) melalui bukunya "Creative Economy, How People Make Money from Ideas". Ide Howkins diinspirasi oleh pemikiran Robert Lucas yang menyatakan pertumbuhan ekonomi suatu tempat sangat ditentukan oleh kreatifitas masyarakat dalam membuat dan mengaplikasikan ilmu pengetahuan untuk menciptakan invovasi. Ditengah persaingan wisata pesisir pantai yang ada di Sanur, ide pengembangan harus melalui kajian yang empiris untuk menciptakan inovasi baru yang membedakan wisata Matahari Terbit dengan wisata pantai lainnya. Permasalahan mitra dalam kegiatan program kemitraan ini yaitu permasalahan kujungan ke Pantai Matahari Terbit yang perlu ditingkatkan, perubahan citra kawasan adat Ngaben menjadi objek wisata, pembenahan warung kuliner dan pengembangan produk kuliner dan oleh-oleh. Adapun solusi yang ditawarkan adalah sebagai berikut. 
1. Penataan dengan merubah citra kawasan pantai Matahari Terbit yang dikenal sebagai jalur adat Ngaben bagi masyarakat Hindu di Sanur menjadi daya tarik wisata dengan penataan dan perencanaan fungsi baru yaitu ruang terbuka dan amphitheater yang bisa di gunakan wisatawan untuk menikmati suasana pantai dan atraksi yang ditawarkan.

2. Konsep penataan mix-used yang bertujuan untuk meningkatkan kunjungan dengan variasi kegiatan yang ditawarkan sehingga persinggungan antar aktivitas akan membangkitkan kebutuhan barum yang juga berdampak pada kualitas suasana kawasan. Dalam hal ini persinggungan antara fungsi atraksi, ruang terbuka, kuliner dan pemandangan pantai sangat berpotensi sebagai motor penggerak wisatawan untuk mengunjungi kawasan Pantai Matahari Terbit.

3. Wantilan sebagai salah satu bangunan wajib untuk memfasilitasi berbagai kebutuhan yang memerlukan ruang besar yang serbaguna.

4. Penataan dan desain warung kuliner sepanjang pantai untuk meningkatkan identitas dan desain yang menarik sehingga mampu dijadikan alat jual kepada wisatawan.

5. Penambahan area decking sebagai ruang transisi antara pejalan kaki dan pemandangan pantai. Area pedestrian ini bisa dimanfaatkan dengan sangat optimal oleh pedagang dan juga bisnis penyeberangan sebagai ruang tunggu atau tempat bersantai.

6. Penataan hutan bakau yang tidak bisa dimanfaatkan dengan baik. Walaupun ukuran yang kecil hutan bakau di kawasan Pantai Matahari Terbit tergolong tidak tepat karena berada tengah lahan setelah penambahan lahan yang dilakukan pada proyek sebelumnya.

\section{Hasil Dan Pembahasan}

\subsection{Pembahasan Konsep Masterplan}

Masterplan atau Rencana Induk adalah dokumen perencanaan jangka panjang yang dinamis yang menggambarkan tata letak secara konseptual untuk memandu dan membatasi pertumbuhan dan pengembangan di masa depan. Rencana induk atau masterplan mencakup analisis dan rekomendasi dari aspek populasi, ekonomi, perumahan, transportasi, fasilitas umum, dan penggunaan lahan. Kajian ini berasal dari masukan dari masyarakat, survei, inisiatif perencanaan dari institusi pemerintah atau stakeholder serta kondisi sosial dan ekonomi. Dalam proses wawancara oleh tokoh masyarakat diperoleh kesimpulan bahwa masterplan penataan ini harus dilakukan oleh pelaku usaha dan masyarakat yang dibantu oleh tokoh masyarakat, pendekatan ini dikenal dengan proses perencanaan pembangunan Bottom-Up. Pendekatan dengan model tersebut merupakan upaya dalam melibatkan semua pihak sejak awal, sehingga proses keputusan diambil dari kesepakatan bersama. Namun beberapa kekurangan dari konsep ini ialah proses penentuan kebijakan yang memakan waktu lama, diperlukan tenaga ahli dalam suatu kajian sehingga memberikan gambaran dan proyeksi yang lebih empiris dalam pengambilan keputusan kedepan.

Selain kajian dari perspektif Arsitektur dan Perencanaan wilayah, kajian dari sudut pandang ekonomi dilakukan demi memeperoleh sistem managemen ekonomi yang baik. Dari beberapa konsep pengembangan ekonomi, pendeakatan yang digunakan yaitu dengan 
membangun ekonomi kreatif yang berwawasan ekowisata yang memerlukan beberapa aspek yaitu kolaborasi antara dunia usaha, industri, kaum intelektual dan pemerintah. Selain kolaborasi antara semua pihak, ide dan gagasan merupakan basis awal terbentuknya ekonomi kreatif yang berkelanjutan tanpa merusak lingkungan sekitar. Dalam beberapa literatur ekonomi kreatif memiliki siklus yang singkat sehingga diperlukan pengembangan secara berkelanjutan demi terciptanya formula yang baik dalam menyiasati keadaan lingkungan yang terus berubah. Berdasarkan kunjungan lapangan dan juga wawancara oleh beberapa toko masyarakat dapat ditarik kesimpulan Masterplan Pantai Matahari Terbit harus memproyeksikan kebutuhan pengembangan yang berkelanjutan yang berbasis ekowisata untuk 5 sampai 7 tahun kedepan. Dalam perencanaan masterplan pada Pantai Matahari Terbit akan meliputi konsep perancanaan arsitektur dan penataan lansekap. Pada tabel dibawah dijabarkan beberapa cangkupan pekerjaan yang dibagi menjadi Kawasan seni dan budaya, Kawasan Penyeberangan dan Kuliner. Tiga kawasan tersebut memiliki ketergantungan satu dengan laitnya selain mampu membangkitkan aktivitas diantara fungsi yang berbeda, kawasankawasan ini mampu menjadi daya tarik tersendiri.

Tabel 1 Prioritas Perencanaan Objek dalam Perencanaan Masterplan Kawasan Matahari Terbit, Sanur.

\begin{tabular}{|c|c|}
\hline OBJEK PERENCANAAN & KETERANGAN \\
\hline Amphiteater & $\begin{array}{l}\text { Perencanaan amphitheater merupakan sebuah } \\
\text { upaya dalam peningkatan daya tarik melalui } \\
\text { atraksi kesenian. Selain memberikan nuansa } \\
\text { baru pada kawasan matahari terbit, } \\
\text { amphitheater mampu menjadi area berkumpul } \\
\text { dan area bersantai bagi pengunjung. }\end{array}$ \\
\hline Kiosk Kuliner & $\begin{array}{l}\text { Penataan area kuliner direncanakan dengan } \\
\text { mempertimbangkan kekuatan dan kenyaman } \\
\text { sehingga didesain dengan dominasi material } \\
\text { bambu sebagai bahan kolom dan atap. }\end{array}$ \\
\hline Wantilan & $\begin{array}{l}\text { Wantilan menjadi salah satu gedung serbaguna } \\
\text { yang diperuntukan untuk kegiatan adat dan } \\
\text { sosial. Wantilan juga mampu menjadi tempat } \\
\text { berteduh dan acara kekeluargaan. }\end{array}$ \\
\hline Petunon & $\begin{array}{l}\text { Penambahan Bale Pewedan dalam upaya untuk } \\
\text { menyediakan sarana dan prasarana yang } \\
\text { memadai untuk prosesi. }\end{array}$ \\
\hline $\begin{array}{l}\text { Ruang Tunggu } \\
\text { Penyeberangan }\end{array}$ & $\begin{array}{l}\text { Pembuatan ruang tunggu yang permanen untuk } \\
\text { pembelian karcis dan proses administrasi. } \\
\text { Perencanaan ruang tunggu bertujuan untuk } \\
\text { meningkatkan kenyamanan penumpang dan } \\
\text { pelaku usaha sehingga citra kawasan } \\
\text { meningkat. }\end{array}$ \\
\hline Mangrove & $\begin{array}{l}\text { Penataan Mangrove atau Hutan Bakau di } \\
\text { kawasan Matahari Terbit merupakan upaya } \\
\text { untuk membenahi dan menata lanskap kawasan } \\
\text { untuk diubah menjadi salah satu destinasi } \\
\text { wisata untuk rekreasi dan edukasi. }\end{array}$ \\
\hline
\end{tabular}

Sumber: Penulis 
Tabel 2 Gambar 3D visual perencanaan objek yang telah disusun berdasarkan kawasan .

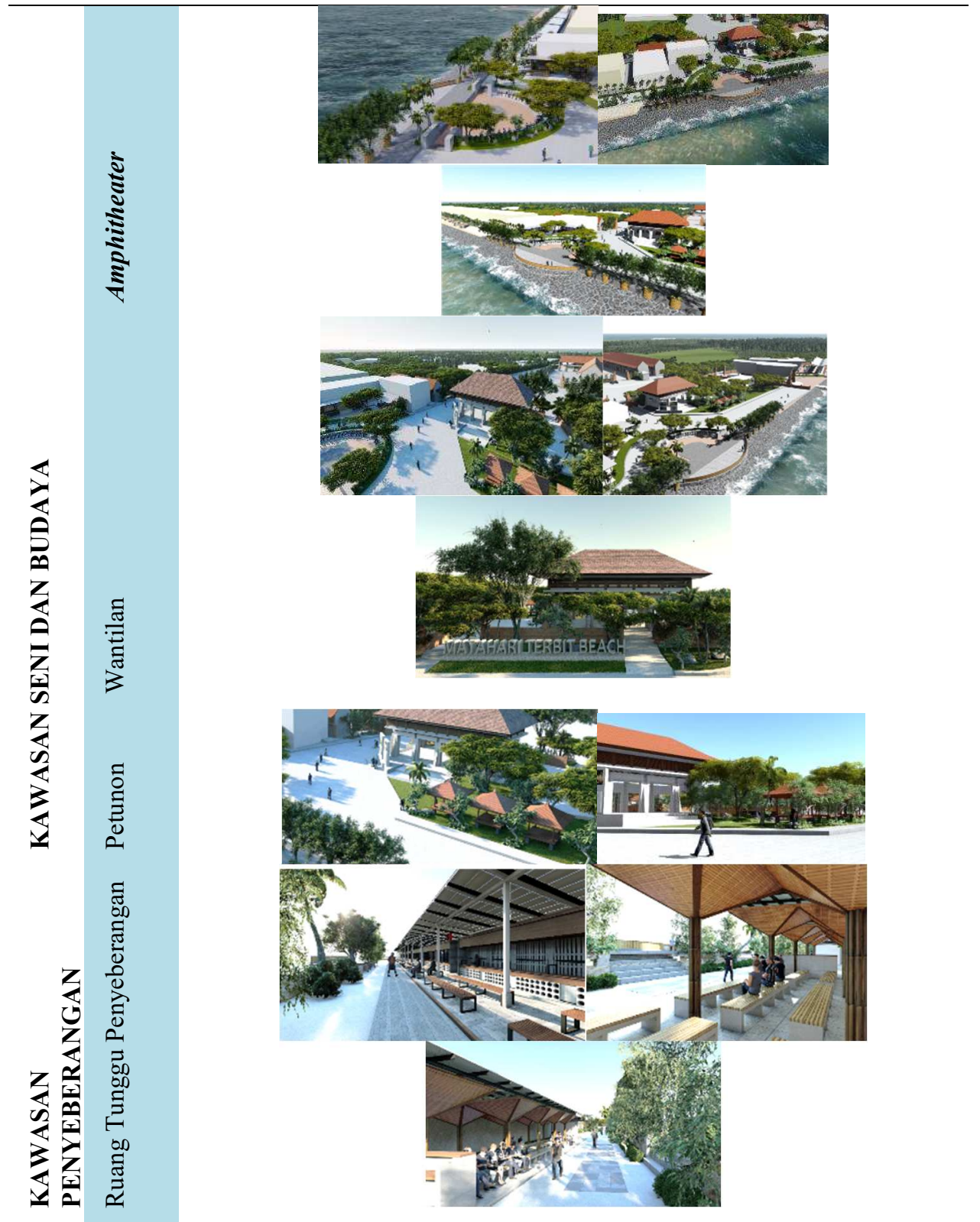




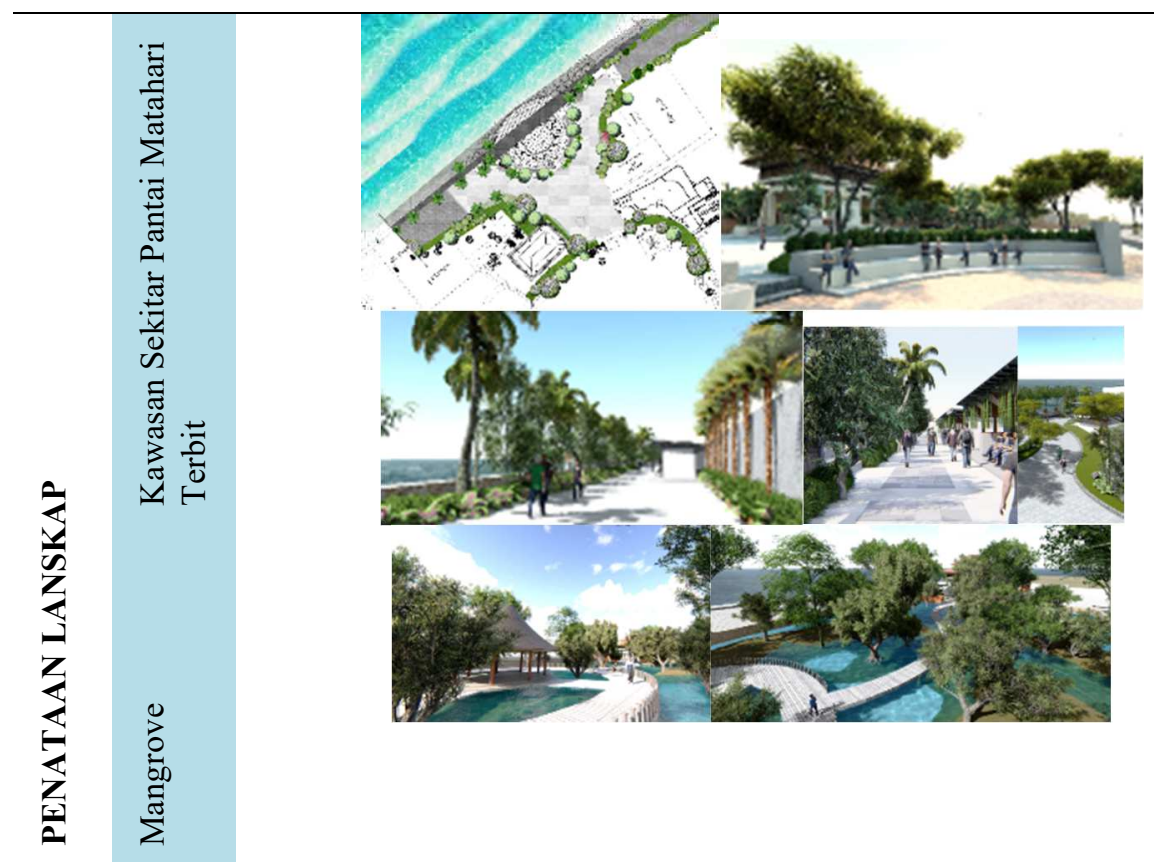

Sumber: Penulis

\section{Kesimpulan}

Penataan kawasan pantai Matahari Terbit merupakan upaya Desa Adat dan Dinas Sanur Kaja dalam memperbaiki kualitas pariwisata Sanur, penataan dengan berbasis ekowisata dan juga pembangunan yang ramah lingkungan menjadi dasar perencanaan dan perancangan masterplan kawasan ini. Pertimbangan dan rapat bersama pihak desa, masyarakat, stakeholder dan pemerintah telah dilakukan dalam mendalami keputusan penting untuk kemajuan pariwisata Sanur.mBerdasarkan keputusan rapat telah diputuskan beberapa objek yang akan direncanakan yaitu pengembangan kawasan seni dan budaya, kawasan penyeberangan, kawasan kuliner, dan penataan lanskap yang diharapkan mampu menjadi objek wisata baru. Berdasarkan sudi kelayakan finansial diputuskan bahwa empat prioritas pengembangan dan penataan objek baru tersebut mampu menghidupkan kawasan pesisi pantai serta memberi dampak positif terhadap ekonomi kerakyatan. Selain itu manajemen atau pola yang dirancang untuk memberikan ruang untuk banjar dalam menggunakan kawasan seni dan budaya untuk mengembangkan dan menjaga seni dan budaya Bali secara khusus. Pengembangan perencanaan masterplan ini diharapakan mampu memberi pedoman kepada pihak Desa Adat dan Dinas dalam mengawal pengembangan pariwisata Bali dan Sanur. Melalui metode Bottom $U p$ ini diharapkan pengembangan Desa diawasi oleh masyarakat yang lekat dengan kondisi dan paham akan potensi, permasalahan, kesempatan dan tantangan kedepan.

Secara garis besar perencanaan dengan metode Bottom Up memerlukan waktu dalam mencapai kesepakat bersama melalui musyawarah yang independen. Selain harus mengesampingkan kepentingan kelompok, proses ini harus bermuara pada kepentingan masyarakat luas. Perencanaan Masterplan harus ditinjau oleh para ahli yang berkecimpung 
dalam pariwisata, ekonomi, arsitektur, perencanaan wilayah kota, para stakeholder, masyarakat dan pemerintah sehingga muncul kolaborasi yang baik dalam bentuk kajian empiris untuk menentukan tindakan 10 tahun kedepan sehingga terciptanya sebuah kawasan yang ramah dan nyaman untuk para wisatawan asing dan lokal.

\section{References}

[1] Geriya. 2000. Transformasi Kebudayaan Bali memasuki Abad XXI. Surabaya: Paramit

[2] John Howkins.2001 The Creative Economy. How people make money from ideas, The Penguin Press.

[3] Soebagyo. 2012. Strategi Pengembangan Pariwisata di Indonesia, dalam Jurnal Liquidity, volume 1 no 2, Juli-Desember 2012. Jakarta Selatan.

[4] The International Network of Sustainable Tourism Observatories (INSTO). http://insto.unwto.org (Diakses pada tanggal 11 Februari 2019) 